Situs Jurnal : http://ejournal.stiepancasetia.ac.id/index.php/jieb

Jilid 6 Nomor 1 Maret 2020

Hal 115 - 128

\title{
PENERAPAN MODEL ALTMAN Z-SCORE DALAM MENGUKUR POTENSI KEBANGKRUTAN (FINANCIAL DISTRESS) \\ (STUDI KASUS PADA PT, BANK TABUNGAN NEGARA (PERSERO) \\ TBK YANG TERDAFTAR DI BURSA EFEK INDONESIA (DATA LAPORAN KEUANGAN TAHUN 2016 \& 2017)
}

\author{
Rofinus Leki (dosen ASN Dpk), Asruni (Dosen Tetap \\ Yayasan),M.Zaid Abdurrakhman (Dosen Tetap Yayasan)
}

Sekolah Tinggi Ilmu Ekonomi Pancasetia BanjarmasinJl. Ahmad Yani

Km.5,5 Banjarmasin, Kalimantas Selatan. e-mail :

yohanr1976@gmail.com

Abstrak: Penelitian dengan menggunakan model Altman Z-score non manufaktur ini, merupakan penelitian lanjutan bertujuan untuk mengungkapkan potensi Financial Distress dari PT.Bank Tabungan Negara (PERSERO) Tbk, di tahun 2016 dan 2017. Hasil penelitian menunjukan bahwa PT. Bank BTN (persero) Tbk memiliki nilai Z-score yang cenderung membaik ditahun 2016 dan 2017 dari pada tahun 2014 dan tahun 2015. PT. Bank BTN (Persero) Tbk. dikategorikan sebagai perusahaan yang berpotensi mengalami financial distress di tahun 2014 dan 2015, dimana nilai z-score yang dimiliki PT. Bank BTN (persero) Tbk. pada saat itu di bawah 1,2 yaitu 0,86 pada tahun 2014, melemah menjadi 0,67 pada tahun 2015. Sedangkan pada tahun 2016 nilai Z-score PT. Bank BTN (persero) Tbk naik menjadi 1,1 dan di tahun 2017 menjadi 1,2 atau sudah berpindah di "grey area". Harapannya adalah bahwa dengan adanya perbaikan kinerja keuangan secara terus menerus dan konsisten, posisi kesehatan keuangan PT. Bank BTN (persero) Tbk dapat segera berpindah ke "zona aman" 


\section{PENDAhuluan}

\section{A.Latar Belakang Masalah}

Peneliitan ini merupakan penelitian lanjutan dari penelitian yg telah dilakukan pada tahun 2016,dengan menggunakan data Laporan Keuangan tahun 2014 dan 2015, dimana dalam penelitian tersebut diperoleh informasi bahwa dari empat Bank Pemerintah yang dianalisis kesehatan keuangannya dengan metode analsisi Altman Z-Srore, salah satu Bank Pemerintah yakni PT, BANK TABUNGAN NEGARA (PERSERO) TBK terdeteksi berpotensi mengalami financial distress. Oleh karena itu dalam penelitian ini peneliti hanya berfokus pada penilaian kondisi keuangan PT, BANK TABUNGAN NEGARA (PERSERO) TBK untuk dua tahun terakhir yakni 2016 - 1017, dengan mengambil judul :

“Analisis Deteksi Potensi Kebangkrutan (Financial Distress) Melalui Altman Ż-Score Studi Kasus Pada PT, BANK TABUNGAN NEGARA (PERSERO) TBK Yang Terdaftar Di Bursa Efek Indonesia (Data Laporan Keuangan Tahun 2016 dan 2017”

\section{A.Rumusan Masalah}

1. Bagaimana hasil dari prediksi potensi kebangkrutan perusahaan perbankan PT, BANK TABUNGAN NEGARA (PERSERO) Tbk. yang terdaftar di Bursa Efek Indonesia tahun 2016 sampai tahun 2017 dengan menggunakan formula model Altman Z Score non manufaktur.

2. Rasio apa saja yang membuat Perusahaan Perbankan PT, BANK TABUNGAN NEGARA (PERSERO) TBK dikategorikan sehat atau berpotensi bangkrut.

\section{B.Tujuan Penelitian}

Untuk memprediksi potensi kebangkrutan pada perusahaan PT, BANK TABUNGAN NEGARA (PERSERO) TBK yang terdaftar pada Bursa Efek Indonesia tahun 2016 dan 2017 dengan menggunakan model Atlman Z-Score, selain itu juga menjawab pertanyaan penulis mengenai penyebab-penyebab perusahaan perbankan tersebut dikategorikan bangkrut menurut model Altman.

\section{LANDASAN TEORI}

\section{A. Pengertian Laporan Keuangan}

Menurut Hery (2012) Laporan keuangan pada dasarnya adalah hasil dari proses akuntansi yang dapat digunakan sebagai alat untuk mengkomunikasikan data keuanangan atau aktivitas perusahaan kepada pihak-pihak yang berkepentingan.

Menurut Ikatan Akuntan Indonesia (2011:5) Laporan Keuangan merupakan suatu penyajian terstruktur dari posisi keuangan dan kinerja keuangan suatu entitas. Laporan keuangan yang lengkap terdiri dari komponen-komponen berikut ini:

1. Laporan posisi keuangan pada akhir periode

2. Laporan laba rugi komprehensif selama periode

3. Laporan perubahan ekuitas selama periode

4. Laporan arus kas selama periode 
5. Catatan atas laporan keuangan

Sedangkan Menurut Baridwan (2010 :17) Laporan keuangan merupakan: "Ringkasan dari suatu proses pencatatan , merupakan suatu ringkasan - ringkasan dari transaksi keuangan yang terjadi tahun buku yang bersangkutan"

Dari definisi-definisi di atas, dapat diketahui bahwa laporan keuangan adalah laporan yang menyajikan informasi yang akan digunakan oleh pihak-pihak yang berkepentingan mengenai posisi keuangan dan kinerja perusahaan yang merupakan hasil dari proses akuntansi selama periode akuntansi dari suatu entitas. Laporan keangan bertujuan untuk menyediakan informasi yang menyangkut posisi keuangan, kinerja, serta perubahan posisi keuangan suatu perusahaan yang bermanfaat bagi sejumlah besar pemakai dalam pengambilan keputusan ekonomi (Baridwan $2010: 3$ )

\section{B.Analisa Laporan Keuangan}

Analisa laporan keuangan penting dilakukan untuk mengetahui kekuatan dan kelemahan suatu perusahaan. Informasi ini diperlukan untuk mengevaluasi kinerja yang dicapai manajemen perusahaan di masa yang lalu, dan juga untuk bahan pertimbangan dalam menyusun rencana perusahaan kedepan. Salah satu cara memperoleh informasi yang bermanfaat dari laporan keuangan perusahaan adalah dengan melakukan analisis rasio keuangan (Sudana 2011:20).

Analisis Raditya (rasio keuangan yang dihasilkan oleh akuntansi keuangan bermanfaat untuk melakukan klasifikasi atau prediksi terhadap kebangkrutan. Analisis kebangkrutan ini dilakukan untuk memperoleh peringatan awal kebangkrutan (tanda-tanda awal kebangkrutan). Semakin awal tanda-tanda kebangkrutan tersebut ditemukan, semakin baik bagi pihak manajemen, karena dapat melakukan perbaikan sejak awal (Hanafi, 2003 : 263 dalam Jurnal akuntansi Yoseph tahun 2011).

\section{C.Pengertian Kebangkrutan}

Menurut Rizki (2014) Kebangkrutan merupakan kegagalan perusahaan dalam menjalankan operasi perusahaan untuk menghasilkan laba. Managemen cukup sering mengalami kegagalan dalam membesarkan perusahaan, akibatnya prospek perusahaan tidak terlihat jelas. Perusahaan menjadi tidak sehat. Bahkan berkelanjutan mengalami krisis yang berkepanjangan akhirnya akan mengarah pada kebangkrutan. Kebangkrutan biasanya diartikan sebagai kegagalan perusahaan dalam menjalankan oprerasi perusahaan untuk menghasikan laba.

Analisis kebangkrutan usaha sangat membantu pembuatan keputusan untuk menentukan sikap terhadap perusahaan yang mengalami kebangkrutan usaha tersebut. Secara umum faktor-faktor penyebab kebangkrutan terdapat pada faktor ekonomi, keuangan, pengalaman, kelainan, bencana dan kecurangan. Sedangkan faktor-faktor penyebab kebangkrutan dapat dibagi menjadi tiga yaitu: faktor umum, faktor external, faktor internal perusahaan.

\section{D.Penilaian Kesehatan Bank}

Berdasarkan Undang-undang Nomor 10 tahun 1998 tentang Perbankan atas Undang-undang Nomor 7 tahun 1992 tentang Perbankan, Bank wajib memelihara tingkat kesehatan bank sesuai dengan ketentuan kecukupan modal, kualitas aset, 
kualitas manajemen, likuiditas, rentabilitas, solvabilitas, dan aspek lain yang berhubungan dengan usaha bank, dan wajib melakukan kegiatan usaha sesuai dengan prinsip kehati-hatian.

Dasar hukum penilaian kesehatan bank tertera pada Peraturan Bank Indonesia (PBI) Nomor 13/1/PB/2011 tanggal 5 Januari 2011 tentang Penilaian Kesehatan Bank Umum. Indikator penilai tingkat kesehatan bank tersebut tertera pada Surat Edaran Bank Indonesia Nomor 13/24/DPNP Tanggal 25 Oktober 2011.

Penilaian tingkat kesehatan bank menggunakan struktur atau komponen CAMELS (Capital, Asset Quality, Management, Earning Power, Liquidity, dan Sensitivity to Market Risk). Penilaian bank tersebut tertuang dalam Peraturan Bank Indonesia Nomor 6/10/PBI/2004 tanggal 12 April 2004 serta Surat Edaran bank Indonesia No.6/23/DPNP tanggal 31 Mei 2004

\section{E.Model Prediksi Kebangkrutan Altman Z-Score}

Menurut Abu Kholid (2012) Z-Score adalah skor yang ditentukan dari hitungan standar kali nisbah-nisbah keuangan yang menunjukkan tingkat kemungkinan kebangkrutan perusahaan. Formula Z-Score untuk memprediksi kebangkrutan dari Altman merupakan sebuah multivariate formula yang digunakan untuk mengukur kesehatan finansial dari sebuah perusahaan. Altman menemukan lima jenis rasio keuangan yang dapat dikombinasikan untuk melihat perbedaan antara perusahaan yang bangkrut dan yang tidak bangkrut.

Analisis Z-Score, penerapan analisis rasio masih terbatas karena dilakukan secara terpisah, artinya setiap rasio diuji secara terpisah. Untuk mengatasi keterbatasan analisa rasio tersebut Altman telah mengkombinasikan beberapa rasio menjadi model prediksi kebangkrutan perusahaan dengan nama Z-Score.Z-Score adalah skor yang ditentukan dari hitungan standar kali nisbah-nisbah keuangan yang akan menunjukkan tingkat kemungkinan kebangkrutan bank. Rasio-rasio tersebut merupakan rasio yang mendeteksi kondisi keuangan perusahaan yang berkaitan dengan likuiditas, profitabilitas dan aktivitas perusahaan. Menurut abu Kholid (2012) Saat ini, formula Z-score untuk perusahaan jenis manufaktur dan nonmanufaktur dibedakan sebagai berikut:

1. Untuk perusahaan manufaktur, menggunakan formula yang terdiri dari 5 koefisien, yakni:

$$
Z=0,717 X_{1}+0,847 X_{2}+3,107 X_{3}+0,420 X_{4}+0,998 X_{5}
$$

Keterangan:

$\mathrm{X} 1$ = Working Capital to Total Assets (Modal Kerja/Total Aset) X2 = Retained Earning to Total Assets (Laba Ditahan/Total Aset)

$\mathrm{X} 3$ = Earning Before Interest and Taxes (EBIT) to Total Assets (Pendapatan Sebelum Dikurangi Biaya Bunga/Total Aset)

X4 = Market Value of Equity to Book Value of Total Liabilities (Harga

Pasar Saham Dibursa/Nilai Total Utang)

X5 = Sales to Total Assets (Penjualan/Total Aset)

Dengan zona diskiriman sbb:

Bila $Z>2,9=$ zona "aman"

Bila $1,23<Z<2,9=$ zona "abu-abu"

Bila $Z<1,23=$ zona "distress" 
2.Untuk perusahaan non-manufaktur, menggunakan formula yang terdiri dari 4 koefisien, yakni:

$Z=6,56 X_{1}+3,26 X_{2}+6,72 X_{3}+1,05 X_{4}$

Dengan zona diskriminan sebagai berikut:

Bila $Z>2,9=$ zona "aman"

Bila $1,22<\mathrm{Z}<2,9$ = zona "abu-abu"

Bila $Z<1,22$ = zona "distress"

Keterangan:

$\mathrm{X} 1=$ Working Capital to Total Assets (Modal Kerja/Total Aset)

$\mathrm{X} 2=$ Retained Earning to Total Assets (Laba Ditahan/Total Aset)

$\mathrm{X} 3$ = Earning Before Interest and Taxes (EBIT) to Total Assets (Pendapatan Sebelum Dikurangi Biaya Bunga/Total Aset)

X4 = Market Value of Equity to Book Value of Total Liabilities (Harga Pasar Saham Dibursa/Nilai Total Utang)

Untuk penelitian ini penulis menggunakan formula Altman yang memiliki 4 rasio karena perbankan BUMN merupakan perusahaan non manufaktur.

Rasio-rasio tersebut terdiri dari :

\section{1) Working Capital Assets/Total Assets (X1)}

Merupakan rasio yang mendeteksi likuiditas yang mengukur kemampuan perusahaan dalam memenuhi kewajiban jangka pendeknya dari total aktiva dan posisi modal kerja. Dimana modal kerja (working capital) diperoleh dari selisih antara aktiva lancar dengan utang lancar. Jika dikaitkan dengan indikatorindikator kebangkrutan seperti yang disebutkan diatas, maka indikator yang dapat digunakan untuk mendeteksi adanya masalah pada tingkat likuiditas perusahaan adalah indikator-indikator internal seperti ketidakcukupan kas, utang dagang membengkak, utilisasi modal (harta kekayaan) menurun, penambahan utang yang tidak terkendali dan beberapa indikator lainnya.

$$
X^{1}=\frac{\text { Working Capital }}{\text { Total Assets }}
$$

\section{2) Retained Earning/Total Assets (X2)}

Rasio ini merupakan rasio profitabilitas yang mendeteksi atau mengukur kemampuan perusahaan dalam menghasilkan keuntungan dalam periode tertentu. Ditinjau dari kemampuan perusahaan yang bersangkutan dalam memproleh laba dibandingkan dengan kecepatan perputaran operating assets sebagai ukuran efisiensi usaha. Manajemen bank sangat berkepentingan untuk dapat melihat rasio ini, karena sekaligus akan terlihat tingkat efisiensi usaha dan kemampuan perusahaan dalam memperoleh laba dari hasil penjualannya.

$$
X^{2}=\frac{\text { Retained Earning }}{\text { Total Assets }}
$$

\section{3) Earning Before Interest and Taxes/Total Assets (X3)}

Rasio ini mengukur kemampuan perusahaan dalam memperoleh laba dari aktiva yang digunakan atau untuk mengukur kemampuan dari modal yang diinvestasikan dalam keseluruhan aktiva untuk memperoleh keuntungan bagi semua investor 
termasuk pemegang saham dan obligasi. Beberapa indikator yang dapat digunakan dalam mendeteksi adanya masalah pada kemampuan profitabilitas perusahaan diantaranya adalah piutang dagang meningkat, rugi terus menerus dalam beberapa kwartal, persediaan meningkat, penjualan menurun, terlambatnya hasil penagihan piutang, kredibilitas perusahaan berkurang serta kesediaan memberi kredit pada konsumen yang tak dapat membayar pada waktu yang ditetapkan.

$$
X^{3}=\frac{E B I T}{\text { Total Assets }}
$$

\section{1) Market Value Of Equity/Book Value Of Total Debt (X4)}

Rasio ini merupakan rasio yang mengukur aktivitas perusahaan. Sering juga digunakan dalam bentuk Net Worth/TotalDebt. Rasio ini mengukur kemampuan perusahaan dalam memberikanjaminan kepada setiap utangnya melalui modalnya sendiri. Untuk mendapatkan Market Value Of Equity dapat diketahui dengan mengalikan jumlah lembar saham yang beredar dengan harga saham (Close). Current liabilities di perbankan yang digunakan terdiri dari kewajiban segera, simpanan nasabah, simpanan dari bank lain, efek, kewajiban deriveratif dan akseptasi, hutang pajak.

\section{$X^{4}=\frac{\text { Market Value of Equity }}{\text { Current Liabilities }}$}

Keempat rasio inilah yang akan digunakan untuk menganalisis laporan keuangan sebuah perusahaan untuk kemudian mendeteksi kemungkinan terjadinya kebangkrutan pada perusahaan tersebut. Dalam manajemen keuangan, rasio-rasio yang digunakan dalam metode Altman ini dapat dikategorikan dalam tiga kelompok besar yaitu:

- Rasio Likuiditas yag terdiri dari X1

- Rasio Profitabilitas yang terdiri dari X2 dan X3

- Rasio Aktivitas yang terdiri dari X4

Beberapa indikator yang dapat digunakan untuk mendeteksi adanya masalah pada aktivitas perusahaan yang kemudian akan berpengaruh terhadap rasio-rasio tersebut di atas adalah pangsa pasar produk kunci menurun, berpindahnya penguasaan pangsa pasar pada pesaing, modal kerja menurun drastis, perputaran persediaan menurun drastis, kepercayaan konsumen berkurang dan beberapa indikator lainnya.

Model Altman (1984) tersebut dapat diterapkan pada masing-masing kelompok perusahaan secara individual ataupun sekelompok perusahaan. Penerapan pada kelompok perusahaan digambarkan oleh Altman dengan mengelompokkan perusahaan menjadi dua kategori yaitu bangkrut dan tidak bangkrut.

Berdasarkan penelitiannya tersebut Altman menemukan lima rasio (untuk perusahaan manufaktur) dan empat rasio untuk perusahaan non manufaktur). Untuk menentukan perusahaan bangkrut dan tidak bangkrut dan menghitung nilai $\mathrm{Z}$ untuk kedua kelompok tersebut. Dalam model tersebut skor 2,90 merupakan 
ambang batas untuk perusahaan sehat.Jadi, perusahaan yang mempunyai skor di atas 2,90 dapat dikatakan sebagai perusahaan sehat. Sedangkan perusahaan yang mempunyai skor dibawah 1,20 akan diklasifikasikan sebagai perusahaan yang potensial bangkrut. Kemudian diantara 1,20 dan 2,90 diklasifikasikan sebagai perusahaan pada grey area (daerah kelabu).

\section{F.Penelitian Terdahulu}

a. Rofinus Leki "Penerapan Model Altman Z-Score dalam mengukur potensi kebangkrutan, Studi Khasus pada Perusahaan Perbankan BUMN yang terdaftara di Bursa Efek Indonesia Tahun 2014 \& 2015. Hasil penelitian menunjukan bahwa dengan menggunakan formula Altman Z-Score non manufaktur, memprediksi potensi kebangkrutan pada perusahaan perbankan BUMN tahun2014 \& 2015 ada pada PT.Bank Tabugnan Negara (Persero) Tbk.

b.Yoseph, "Analisis Kebangkrutan Dengan Metode Z-Score Altman, Springgate dan Zmijewski Pada Perusahaan PT Indofood Sukses Makmur Tbk Periode 2005-2009" Tahun 2011. perusahaan kurang dapat memanfaatkan aset-aset dan ekuitas yang dimilikinya sehingga perusahaan tersebut kurang efektif. Perusahaan harus dapat lebih mengontrol akan kewajibannya agar tidak terjadi peurunan pada nilai variabel kebangkrutan, penurunan pada veriabel-veriabel kebangkrutan yang terjadi pada periode 2007-2008 dikarenakan peningkaran kewajiban yang tidak diiringi dengan peningkatan pada kinerja keuangan.

c.Rismawaty, "Analisis Perbandingan Model Prediksi Financial Distress Altman, Springate, ohlson dan Zmijewsi (Studi Empiris pada perusahaan Manufaktur yang ada di Bursa Efek Indonesia)" Tahun 2011. Memilih sampel secara matched-paired seluruh sampel berjumlah 48 perusahaan, terdiri dari 24 perusahaan yang mengalami financial distress dan 24 yang tidak mengalami financial distress. Model Zmijewski adalah model yang paling sesuai diterapkan untuk perusahaan manufaktur di Indonesia, karena tingkat keakuratannya paling tinggi dibandingkan model prediksi lainnya. Setelah dilakukan prediksi terhadap 18 perusahaan diluar sampel menggunakan model Zmijewski, diketahui bahwa ada 5 perusahaan yang diprediksi akan mengalami financial distress di masa depan, yaitu PT Alam Karya Unggul Tbk, PT Gajah Tunggal Tbk, PT Kertas Basuki Rachmat Indonesia Tbk, PT Apac Citra Centertex Tbk, dan PT Primarindo Asia Infrastructure Tbk

\subsection{Kerangka Berfikir}

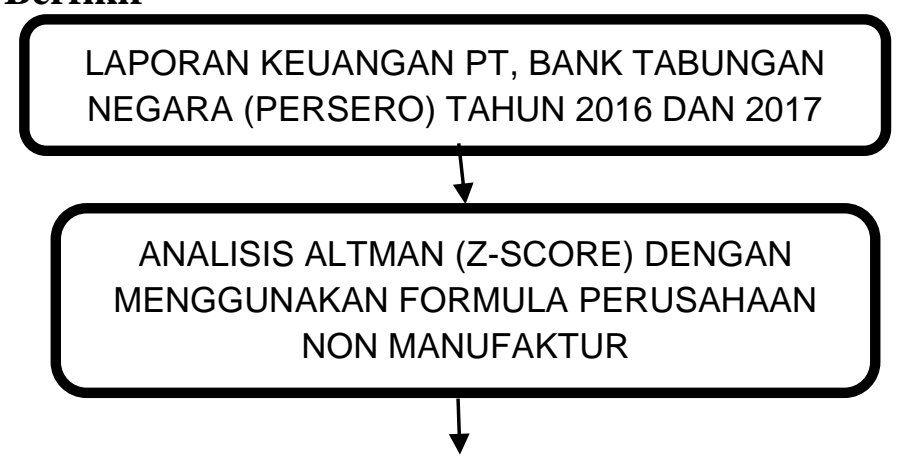




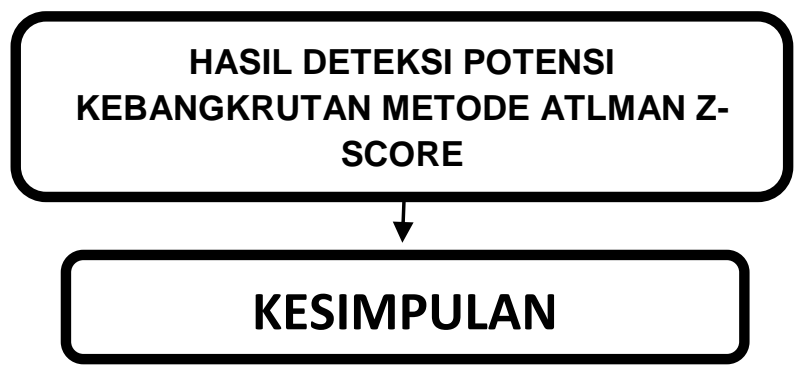

Sumber : Diolah peneliti.

\section{METODOLOGI PENELITIAN}

Penelitian ini adalah merupakan penilitian deskriptif, yakni dengan menggunakan data laporan keuangan perusahaan dan kemudian diolah dengan metode Altman Z-Score, untuk menghasilkan informasi yang dapat mendeskripsikan kondisi disaat perusahaan mengalami ketidakcukupan dana untuk menjalankan usahanya. Kebangkrutan biasanya dihubungkan dengan kesulitan keuangan.

Sumber data yang digunakan adalah Laporan keuangan PT. Bank Tabungan Negara (PERSERO) Tbk.(Data Laporan Keuangan tahun 2016 sampai dengan 2017), yang sudah dipublikasikan di Bursa, dapat diakses melalui webside BEI www.idx.co.id. Sedangkan teknik pengumpulan data dengan metode dokumentasi, yakni dengan mencari data mengenai variabel yang berupa laporan keuangan serta buku-buku yang menunjang penelitian.

\section{HASIL PENELITIAN DAN PEMBAHASAN}

\section{A.Hasil Penelitian}

Berikut merupakan rincian perhitungan dari rasio Altman Z-Score pada PT, BANK TABUNGAN NEGARA (PERSERO) TBK yang terdaftar di Bursa Efek Indonesia tahun 2016 dan tahun 2017 :

1) Working Capital Assets toTotal Assets $\left(X_{1}\right)$

Merupakan rasio yang mendeteksi likuiditas yang mengukur kemampuan perusahaan dalam memenuhi kewajiban lancar atau jangka pendeknya dari total aktiva dan posisi modal kerja. Dimana modal kerja (working capital) diperoleh dari selisih antara aktiva lancar dengan utang lancar atau ini disebut sebagai modal kerja bersih. Sedangkan total aset adalah semua aset yang dimiliki oleh perusahaan.

Tabel 1 : Total Asset PT. Bank Tabungan Negara (Persero) Tbk. tahun 2016 dan tahun 2017 (dalam jutaan Rupiah)

\begin{tabular}{|l|c|}
\hline KETERANGAN & $(\boldsymbol{R p})$. \\
\hline TOTAL ASSET TH 2916 & 214.168 .479 \\
\hline TOTAL ASSET TH 2017 & 261.365 .267 \\
\hline
\end{tabular}

Sumber : $\underline{w w w . i d x . c o . i d}$

Tabel 2 : Working Capital PT. Bank Tabungan Negara (Persero) Tbk. tahun 2016 dan tahun 2017 (dalam jutaan Rupiah)

\begin{tabular}{|l|r|}
\hline KETERANGAN & (Rp.) \\
\hline TOTAL WORKING CAPITAL 2016 & 205.909 .003 \\
\hline TOTAL WORKING CAPITAL 2017 & 252.441 .806 \\
\hline
\end{tabular}


Sumber : www.idx.co.id

Dari data di atas maka dapat dihitung rasio X1 dengan cara Working Capital dibagi Total Asset, maka akan diperoleh hasil sebagai berikut :

$X 1=\frac{\text { Working Capital }}{\text { Total Assets }}$

Tabel 3 : Perhitungan $X_{1}$ PT. Bank Tabungan Negara (Persero) Tbk. tahun 2016 dan tahun 2017

\begin{tabular}{|l|c|l|}
\hline KETERANGAN & $\begin{array}{c}\text { WORKING } \\
\text { CAPITAL / } \\
\text { TOTAL ASSET }\end{array}$ & \multicolumn{1}{|c|}{ Variabel X1 } \\
\hline TAHUN 2016 & $\frac{205.909 .003}{214.168 .479}$ & 0.9614 \\
\hline TAHUN 2017 & $\frac{252.441 .806}{261.365 .267}$ & 0.9658 \\
\hline
\end{tabular}

Sumber : Data Diolah

\section{2) Retained Earning/Total Assets $\left(\mathrm{X}_{2}\right)$}

Rasio ini merupakan rasio profitabilitas yang mendeteksi atau mengukur kemampuan perusahaan dalam menghasilkan keuntungan dalam periode tertentu. Ditinjau dari kemampuan perusahaan yang bersangkutan dalam memproleh laba dibandingkan dengan kecepatan perputaran operating assets sebagai ukuran efisiensi usaha. Manajemen bank sangat berkepentingan untuk dapat melihat rasio ini, karena sekaligus akan terlihat tingkat efisiensi usaha dan kemampuan perusahaan dalam memperoleh laba dari hasil penjualannya.

Tabel 4 : Retained Earning PT. Bank Tabungan Negara (Persero) Tbk. tahun 2016 dan tahun 2017 (dalam jutaan Rupiah)

\begin{tabular}{|l|c|}
\hline KETERANGAN & ( $\boldsymbol{R p}$.) \\
\hline RETAINED EARNING 2016 & 2.618 .905 \\
\hline RETAINED EARNING 2017 & 3.027 .466 \\
\hline
\end{tabular}

Sumber : www.idx.co.id

Dari data di atas maka dapat dihitung rasio X2 dengan cara Retained Earning dibagi Total Asset, maka akan diperoleh hasil sebagai berikut :

$$
X 2=\frac{\text { Retained Earning }}{\text { TotalAssets }}
$$

Tabel 5 : Perhitungan $\mathrm{X}_{2}$ PT. Bank Tabungan Negara (Persero) Tbk. tahun 2016 dan tahun 2017 


\begin{tabular}{|l|c|c|}
\hline \multicolumn{1}{|c|}{ KETERANGAN } & $\begin{array}{c}\text { RETAINED } \\
\text { EARNING / } \\
\text { TOTAL ASSET }\end{array}$ & Variabel X2 \\
\hline X2 TAHUN 2016 & $\frac{2.618 .905}{214.168 .479}$ & 0.01222 \\
\hline X2 TAHUN 2017 & $\frac{3.027 .466}{261.365 .267}$ & 0,01158 \\
\hline
\end{tabular}

Sumber : Data diolah

\section{3) Earning Before Interest and Taxes toTotal Assets $\left(\mathrm{X}_{3}\right)$}

Rasio ini menunjukkan kemampuan perusahaan untuk menghasilkan laba dari aktiva perusahaan, sebelum pembayaran bunga dan pajak. Melemahnya faktor ini merupakan indikator terbaik akan hadirnya kebangkrutan. Berikut ini adalah tabel 4.6 yang menunjukkan besarnya laba sebelum bunga dan pajak yang dimiliki masing-masing perusahaan perbankan tersebut.

Tabel 6 : PT. Bank Tabungan Negara (Persero) Tbk. tahun 2016 dan tahun 2017 (dalam jutaan Rupiah)

\begin{tabular}{|l|c|}
\hline NAMA BANK & ( Rp.) \\
\hline EBIT TAHUN 2016 & 3.352 .232 \\
\hline EBIT TAHUN 2017 & 3.891 .903 \\
\hline
\end{tabular}

\section{Sumber : www.idx.co.id}

Dari data di atas maka dapat dihitung rasio X3 dengan cara EBIT dibagi

Total Asset, maka akan diperoleh hasil sebagai berikut :

$X 3=\frac{E B I T}{\text { TotalAssets }}$

Tabel 7 : Perhitungan $X_{3}$ PT. Bank Tabungan Negara (Persero) Tbk. tahun 2016 dan tahun 2017

\begin{tabular}{|l|r|}
\hline KETERANGAN & \multicolumn{1}{|l|}{ Variabel X3 } \\
\hline TAHUN 2016 & 0,01565 \\
\hline TAHUN 2017 & 0,01489 \\
\hline
\end{tabular}

Sumber : Data Diolah

\section{4) Market Value of Equity to Book Value of Total Liabilities $\left(\mathbf{X}_{4}\right)$}

Rasio ini menunjukkan kemampuan perusahaan untuk memenuhi kewajibankewajiban dari nilai pasar modal sendiri (saham biasa). Nilai pasar ekuitas sendiri diperoleh dengan mengalikan jumlah lembar saham biasa yang beredar dengan harga 
pasar per lembar saham biasa (close review). Nilai buku hutang diperoleh dengan menjumlahkan kewajiban lancar dengan kewajiban jangka panjang.

Berikut ini akan diperlihatkan jumlah lembar saham dan harga pasar saham per lembar saham biasa (Close Preview).

\section{Market Value of Equity = (Jumlah lembar saham)X (Harga saham)}

Tabel 8 : Jumlah Saham yang berredar pada akhir tahun dan Close preview Tahun 2016 dan tahun 2017

\begin{tabular}{|c|c|c|c|}
\hline KETERANGAN & $\begin{array}{c}\text { JUMLAH } \\
\text { LEMBAR } \\
\text { SAHAM } 2016 \\
\end{array}$ & $\begin{array}{c}\text { CLOSE } \\
\text { PREVIEW } \\
2016 \\
\end{array}$ & $\begin{array}{c}\text { Market Value of } \\
\text { Equity to Book } \\
\text { Value } 2016\end{array}$ \\
\hline TAHUN 2016 & 10.590 .000 .000 & $\mathrm{Rp} 2.480$ & 26.263.200.000.000. \\
\hline KETERANGAN & $\begin{array}{c}\text { JUMLAH } \\
\text { LEMBAR } \\
\text { SAHAM } 2017 \\
\end{array}$ & $\begin{array}{c}\text { CLOSE } \\
\text { PREVIEW } \\
2017 \\
\end{array}$ & $\begin{array}{c}\text { Market Value of } \\
\text { Equity to Book } \\
\text { Value } 2017\end{array}$ \\
\hline TAHUN 2017 & 10.590 .000 .000 & $\mathrm{Rp} 3.570$ & 37.806 .300 .000 .000 \\
\hline
\end{tabular}

Sumber : idx.co.id

Tabel 9 : Total Liabities PT. Bank Tabungan Negara (Persero) Tbk. tahun 2016 dan tahun 2017 (dalam jutaan Rupiah)

\begin{tabular}{|l|c|}
\hline \multicolumn{1}{|c|}{ KETERANGAN } & (Rp.) \\
\hline TOTAL LIABILITIES 2016 & 182.828 .998 \\
\hline TOTAL LIABILITIES 2017 & 223.937 .463 \\
\hline
\end{tabular}

Sumber: www.idx.co.id

Dari data di atas maka akan dapat di hitung rasio $\mathrm{X}_{4}$ dengan membagi Market Value of Equity to Book dengan Total Liabilites.

$$
X 4=\frac{\text { Market Value of Equity }}{\text { Total Liabilities }}
$$

Tabel 10 : Perhitungan Rasio $\mathrm{X}_{4}$ PT. Bank Tabungan Negara (persero) Tbk. tahun 2016 dan tahun 2017

\begin{tabular}{|c|c|c|c|}
\hline KETERANGAN & $\begin{array}{c}\text { Market Value of } \\
\text { Equity to Book } \\
\text { Value 2016 }\end{array}$ & $\begin{array}{c}\text { TOTAL } \\
\text { LIABILITIES } \\
2016\end{array}$ & $\begin{array}{c}\text { X4 } \\
\text { Tahun } \\
\mathbf{2 0 1 6}\end{array}$ \\
\hline TAHUN 2016 & 26.263 .200 & 182.828 .998 & $\mathbf{0 . 1 4 3 6}$ \\
\hline KETERANGAN & $\begin{array}{c}\text { Market Value of } \\
\text { Equity to Book } \\
\text { Value 2017 }\end{array}$ & $\begin{array}{c}\text { TOTAL } \\
\text { LIABITIES } \\
2017\end{array}$ & $\begin{array}{c}\text { X4 } \\
\text { Tahun } \\
\mathbf{2 0 1 7}\end{array}$ \\
\hline
\end{tabular}




\begin{tabular}{|l|l|l|l|}
\hline TAHUN 2017 & 37.806 .300 & 223.937 .463 & $\mathbf{0 . 1 6 8 8}$ \\
\hline
\end{tabular}

Sumber : Data Diolah

Dari data di atas maka dapat ditetukan rasio $\mathrm{X} 1, \mathrm{X} 2, \mathrm{X} 3$ dan $\mathrm{X} 4$ dan dapat dimasukan ke dalam formula Z-Score Non Manufaktur untuk Perbankan BUMN tahun 2016 dan tahun 2016 dengan rincian perhitungan sebagai berikut:

$\mathrm{Z}-$ Score $=6,56 \mathrm{X}_{1}+3,26 \mathrm{X}_{2}+6,72 \mathrm{X}_{3}+1,05 \mathrm{X}_{4}$

Tabel 11 : Perhitungan Metode Altman Z-Score Non Manufaktur PT. BANK

TABUNGAN NEGARA (PERSERO) Tbk. tahun 2016 dan tahun 2017

\begin{tabular}{|l|l|r|r|r|r|}
\hline KETERANGAN & $\mathbf{6 , 5 6}(\mathbf{X 1})$ & $\mathbf{3 , 2 6}(\mathbf{X 2})$ & $\mathbf{6 , 7 2}(\mathbf{X 3})$ & $\mathbf{1 , 0 5}(\mathbf{X} 4)$ & $\begin{array}{l}\text { Z SCORE } \\
\text { TAHUN 2016 }\end{array}$ \\
\hline TAHUN 2016 & 0.9614 & 0.0122 & 0.0157 & 0.1436 & $\mathbf{1 . 1 3 2 9}$ \\
\hline KETERANGAN & $\mathbf{6 , 5 6}(\mathbf{X 1})$ & $\mathbf{3 , 2 6}(\mathbf{X 2})$ & $\mathbf{6 , 7 2}(\mathbf{X 3 )}$ & $\mathbf{1 , 0 5}(\mathbf{X} 4)$ & $\begin{array}{l}\text { Z SCORE } \\
\text { TAHUN 2017 }\end{array}$ \\
\hline TAHUN 2017 & 0.9658 & 0.0116 & 0.0149 & 0.1688 & $\mathbf{1 . 1 6 1 1}$ \\
\hline
\end{tabular}

Sumber: Data Diolah

Setelah diproleh nilai dari Z-Score, maka dapat diperoleh hasil sebagai berikut.

Tabel 12 : Hasil Metode Altman Z-Score Non Manufaktur PT. Bank

Tabungan Negara (Persero) Tbk. tahun 2016 dan tahun 2017

\begin{tabular}{|l|c|c|}
\hline KETERANGAN & Z SCORE TAHUN 2016 & KETERANGAN \\
\hline TAHUN 2016 & $\mathbf{1 . 1}$ & GREY AREA \\
\hline & & KETERANGAN \\
\hline KETERANGAN & Z SCORE TAHUN 2017 & GREY AREA \\
\hline TAHUN 2017 & $\mathbf{1 . 2}$ & \\
\hline
\end{tabular}

Sumber : Data diolah

\section{A. Pembahasan}

Altman menggunakan empat rasio keuangan untuk menilai kecenderuangan perusahaan menjadi bangkrut atau tidak bangkrut dan menghitung nilai $\mathrm{Z}$ atau dikenal dengan Z-Score. Dalam model tersebut skor 2,90 merupakan ambang batas untuk perusahaan sehat. Jadi, perusahaan yang mempunyai skor di atas 2,90 dapat dikatakan sebagai perusahaan sehat. Sedangkan perusahaan yang mempunyai skor dibawah 1,20 akan diklasifikasikan sebagai perusahaan yang potensial bangkrut. Kemudian diantara 1,20 dan 2,90 diklasifikasikan sebagai perusahaan pada grey area(daerah kelabu).

$>$ Z-Score $>2,9$ maka diklasifikasikan sebagai perusahaan yang sehat

$>$ Z-Score 1,2 sampai 2,9 maka perusahaan tersebut berada pada area abuabu (Grey) 
Z-Score $<$ 1,2 maka diklasifikasikan sebagai perusahaan yang berpotensi bangkrut

Dari perhitungan Altman Z-Score berdasarkan laporan keuangan tahun 2016 dan 2017 maka diperoleh hasil bahwa :

PT. Bank BTN (persero) Tbk memiliki nilai Z-score cenderung membaik ditahun 2016 dan 2017 dari pada tahun 2014 dan tahun 2015. PT. Bank BTN (Persero) Tbk. dikategorikan sebagai perusahaan yang berpotensi bangkrut di tahun 2014 dan 2015, daimana nilai z-score yang dimiliki PT. Bank BTN (persero) Tbk. pada saat itu di bawah 1,2 yaitu 0,86 pada tahun 2014, melemah menjadi 0,67 pada tahun 2015 . Sedangkan pada tahun 2016 nilai Z-score PT. Bank BTN (persero) Tbk naik menjadi 1,1 dan di tahun 2017 menjadi 1,2 atau sudah berpindah di "grey area" ini menunujukan adanya perbaikan kinerja keuangan yang cukup baik dan signifikan dari pihak manajemen dalam memperkuat ratio-ratio penilaian. Harapannya adalah bahwa dengan adanya perbaikan kinerja keuangan secara terus menerus dan konsisten, posisi kesehatan keuangan PT. Bank BTN (persero) Tbk dapat segera berpindah ke "zona aman".

\section{KESIMPULAN DAN SARAN}

\section{Kesimpulan}

a. Hasil analisis deteksi potensi kebangkrutan dengan menggunakan formula Altman Z Score non manufaktur pada PT. Bank BTN (persero) Tbk, berdasarkan data Laporan Keuangan tahun 2016 dan 2017 mengungkapkan bahwa saat ini PT. Bank BTN (persero) Tbk ada dalam "grey area".

b.Rasio yang berpengaruh tehadap tingkat kesehatan Keuangan PT. Bank BTN (persero) Tbk, seperti untuk ratio X1, X2, X3 dan X4 harus di perkuat dengan fokus pada pengendalian variabel utama yang mempengaruhi ratio-ratio tersebut. Current asset misalnya, sebaiknya diperkuat agar dapat menutupi current liabilities sehingga working capital yang dimiliki tidak menjadi negativ. Investasi pada piutang yang terlalu besar juga berbahaya sebab dapat mengakibatkan kinerja perusahaan menjadi terganggu. Apabila terjadi gangguan terhadap piutang maka hal tersebut akan mengganggu perusahaan karena secara tidak langsung itu akan berdampak pada penerimaan kas perusahaan di masa yang akan datang. Kemudian persediaan yang juga terlalu besar dapat menyebabkan perusahaan menjadi kurang likuid. Biaya-biaya operasional perusahaan juga perlu diperhatikan penggunaannya agar lebih efisien jangan sampai lebih besar daripada pendapatan yang dihasilkan oleh perusahaan.

\section{DAFTAR PUSTAKA}


Baridwan, Zaki. 2010. Intermediate Accounting. Edisi 8. BPFE. Yogyakarta.

Harahap, Sofyan Safri. 2009. Analisis Kritis atas Laporan Keuangan. Jakarta : PT. Raja Grafindo Persada.

Hery, 2012. Mengenal dan Memahami Laporan Keuangan, CAPS, Jogjkarta

Ikatan Akuntan Indonesia, 2011. Pernyataan Standar Akuntansi Keuangan per Januari 2011, Jakarta

Kasmir, 2011. Analisis Laporan Keuangan. Catatan Keempat, PT. Raja Grafindo Persada, Jakarta.

Kholid, Abu, 2012, Altman Z-score: Model Untuk Memprediksi Kesulitan Keuangan Perusahaan, http://accounting.binus.ac.id (diakses tanggal 20 Mei 2015)

Sudana, Made I, 2011. Manajemen Keuangan Perusahaan Teori \& Praktik. PT Gelora Aksara Pratama. Surabaya

Rismawaty, 2011. Analisis Perbandingan Model Prediksi Financial Distress Altman, Springate, Ohlson dan Zmijewski (Studi Empiris pada Perusahaan Manufaktur yang Terdaftar di Bursa Efek Indonesia. Universitas Hasanuddin, Makassar

Rofinus Leki, 2016. Penerapan Model Altman Z-Score Dalam mengukur Potensi Kebangkurutan (Studi Kasus Pada Perusahaan Perbankan BUMN Yang terdaftar pada Bursa Efek Indonesia Tahun 2014 dan 2015)

Suciati, Amelia, 2012, Camels Dalam Perbankan, http://melzdsnih.blogspot.com (diakses tanggal 2 Agustus 2015)

Yoseph, 2011. Analisis Kebangkrutan dengan Metode Z-Score Altman, Springate dan Zmijewski Pada PT Indofood Sukses Makmur Tbk Periode 2005 2009, Jurnal Akuntansi. Universitas Kristen Maranatha.

www.idx.co.id 